\title{
PENGARUH MODEL PEMBELAJARAN ROLE PLAYING BERBANTUAN TEKS DIALOG TERHADAP KOMPETENSI KETERAMPILAN BERBICARA DALAM BAHASA INDONESIA
}

\author{
I A Md Widyari', Ni Nyoman Ganing ${ }^{2}$, I G A A Sri Asri ${ }^{3}$ \\ 1,2,3 Jurusan PGSD, Universitas Pendidikan Ganesha, Singaraja, Indonesia \\ e-mail: widyaridayu@gmail.com ${ }^{1}$, nyomanganing@yahoo.co.id ${ }^{2}$, igaagungsri.asri@undiksha.ac.id ${ }^{3}$
}

\begin{abstract}
Abstrak
Penelitian ini bertujuan untuk mengetahui perbedaan yang signifikan kompetensi keterampilan berbicara dalam bahasa Indonesia antara kelompok siswa yang dibelajarkan dengan menggunakan model pembelajaran role playing berbantuan teks dialog dengan kelompok siswa yang dibelajarkan dengan menggunakan pembelajaran konvensional pada siswa kelas IV SD Gugus Budi Utomo tahun ajaran 2017/2018. Jenis penelitian ini merupakan quasi experimental design dengan bentuk non-equivalent post-test only control group design. Populasi penelitian ini adalah seluruh siswa kelas IV SD Gugus Budi Utomo, yang berjumlah 315 siswa. Sampel ditentukan menggunakan teknik sampel kelompok. Sampel dalam penelitian ini adalah siswa kelas IVB SD Negeri 6 Kesiman berjumlah 31 siswa sebagai kelompok eksperimen dan siswa kelas IV SD Negeri 14 Kesiman berjumlah 38 siswa sebagai kelompok kontrol. Instrumen untuk mengumpulkan data adalah rubrik penilaian. Data yang diperoleh dianalisis menggunakan uji t. Hasil analisis menunjukkan terdapat perbedaan yang signifikan kompetensi keterampilan berbicara dalam bahasa Indonesia antara kelompok siswa yang dibelajarkan dengan model pembelajaran role playing berbantuan teks dialog dengan kelompok siswa yang dibelajarkan menggunakan pembelajaran konvensional pada siswa kelas IV SD Gugus Budi Utomo Denpasar Timur tahun pelajaran 2017/2018. Hal tersebut dibuktikan dengan hasil $t_{\text {hitung }}=3,81>t_{\text {tabel }}=$ 2,00 pada taraf signifikansi $5 \%$ dan $\mathrm{dk}=67$. Nilai rata-rata kompetensi keterampilan berbicara dalam bahasa Indonesia kelompok eksperimen $\overline{\mathrm{X}}=85,00>\overline{\mathrm{X}}=76,45$ kelompok kontrol. Dapat disimpulkan terdapat pengaruh model pembelajaran role playing berbantuan teks dialog terhadap kompetensi keterampilan berbicara dalam bahasa Indonesia siswa kelas IV SD Gugus Budi Utomo tahun ajaran 2017/2018.
\end{abstract}

Kata kunci : $\quad$ role playing, teks dialog, keterampilan berbicara.

\begin{abstract}
This study aims to know significant differences in the competence of speaking skill in Indonesian between groups of students who were taught by role playing learning model aided text dialogue and groups of students who were taught by conventional learning at IV grade Elementary School students of Gugus Budi Utomo academic year of 2017/2018. This research was a quasi experimental design with a non-equivalent post-test only control group design. The population of this research is all IV grade Elementary School students of Gugus Budi Utomo, amounting to 315 students. The sample was determined using group sample technique. The sample in this research is the students of IVB grade Elementary School students 6 Kesiman amounting to 31 students as experimental group and IV grade Elementary School students 14 Kesiman amounting to 38 students as control group. The instrument for collecting data is the scoring rubric. The data obtained were analyzed by t-test. The result of the analysis shows that there is a significant difference of competence of speaking skill in Indonesian between group of students who were taught by role playing learning model aided text dialogue and groups of students who were taught by conventional learning at IV grade Elementary School students of Gugus Budi Utomo academic year of $2017 / 2018$. This is evidenced by the result $t_{\text {count }}=3,81>$ $t_{\text {table }}=2,00$ at $5 \%$ significance level and $\mathrm{dk}=67$. The average score competence of speaking skill in Indonesian experimental group $\overline{\mathrm{X}}=85,00>\overline{\mathrm{X}}=76,45$ control group. It can be concluded that there is influence of role playing learning model aided text dialogue to
\end{abstract}


competence of speaking skill in Indonesian of IV grade Elementary School students of Gugus Budi Utomo academic year of 2017/2018.

Kata kunci : $\quad$ role playing, text dialogue, speaking skill.

\section{Pendahuluan}

Pendidikan merupakan wahana untuk meningkatkan dan mengembangkan kualitas sumber daya manusia untuk memperoleh pengetahuan, pemahaman, dan cara bertingkah laku yang sesuai dengan kebutuhan masa depan dan arah hidup siswa. Dalam penyelenggaraan pendidikan di Indonesia, salah satu jenjang pendidikan yang memegang peranan penting adalah siswa SD. Maka dari itu dalam pendidikan siswa SD perlu diperhatikan kegiatan pembelajaran yang digunakan. Sesuai dengan UU RI No. 20 tahun 2003 tentang sistem pendidikan nasional, didefinisikan kurikulum adalah seperangkat rencana dan pengaturan mengenai tujuan, isi, dan bahan pelajaran serta cara yang digunakan sebagai pedoman penyelenggaraan kegiatan pembelajaran untuk mencapai tujuan pendidikan tertentu. Salah satu usaha pemerintah untuk memperbaiki kualitas mutu pendidikan agar dapat mencetak manusia yang berkualitas adalah dengan memperbaiki kurikulum. Kurikulum merupakan suatu rencana pendidikan yang memberikan pedoman dan pegangan mengenai tujuan, isi, dan bahan pelajaran serta cara yang digunakan sebagai pegangan penyelenggaraan kegiatan pembelajaran guna mencapai tujuan pendidikan.

Kurikulum 2013 sebagai kurikulum yang diterapkan di Indonesia, memiliki kompetensi inti yang terdiri atas empat aspek, yaitu: kompetensi inti-1 (KI-1) untuk aspek sikap spiritual, kompetensi inti-2 (KI-2) untuk aspek sikap sosial, kompetensi inti-3 (KI-3) untuk aspek pengetahuan, dan kompetensi inti-4 (KI-4) untuk aspek keterampilan. Selain itu, kurikulum 2013 memiliki tujuan yaitu untuk meningkatkan rasa ingin tahu siswa dan mendorong siswa menjadi lebih aktif. Proses pembelajaran kurikulum 2013 menggunakan sistem terintegrasi dengan menggunakan tema, dimaksudkan untuk mengaitkan beberapa mata pelajaran ke dalam satu pokok pembahasan, sehingga pemisahan antar mata pelajaran tidak terlalu terlihat jelas. Salah satu mata pelajaran yaitu muatan materi bahasa Indonesia.

Bahasa adalah alat komunikasi yang bersifat sistematik, mana suka, ujar, manusiawi, komunikatif, dan dipergunakan oleh setiap individu. Hal serupa disampaikan Priyatni (2014:118) bahwa "bahasa adalah alat komunikasi". Muatan materi bahasa Indonesia di SD diarahkan untuk meningkatkan kemampuan peserta didik untuk memahami dan menggunakan bahasa sebagai alat komunikasi dengan baik dan benar, baik secara lisan maupun tulis. "Tujuan pengajaran bahasa Indonesia di SD antara lain bertujuan agar siswa mampu menikmati dan memanfaatkan karya sastra untuk mengembangkan kepribadian, memperluas wawasan kehidupan, serta meningkatkan pengetahuan, dan kemampuan berbahasa" (Susanto, 2014:245). Oleh sebab itu, muatan materi bahasa Indonesia di sekolah seharusnya menjadi pembelajaran yang menyenangkan dan interaktif bagi siswa, yang memberikan kesempatan pada guru dan siswa untuk terlibat secara aktif dalam menggunakan dan mengembangkan keterampilan-keterampilan berbahasa khususnya pengembangan kompetensi keterampilan berbicara. Ruang lingkup muatan materi bahasa Indonesia terdapat empat keterampilan dasar berbahasa, yaitu menyimak, berbicara, membaca, dan menulis. Salah satu keterampilan berbahasa yang memiliki peran penting untuk menciptakan siswa yang aktif dan kreatif dalam pembelajaran bahasa Indonesia adalah keterampilan berbicara.

Aspek keterampilan tercantum dalam kompetensi inti 4 (KI-4) sebagai kelanjutan dari aspek pengetahuan (kompetensi inti 3 atau $\mathrm{KI}-3$ ) yang telah dikuasai siswa. Jadi, kompetensi pengetahuan mencerminkan "tahu", sedangkan kompetensi keterampilan mencerminkan "bisa". Oleh sebab itu, muatan materi bahasa Indonesia di sekolah seharusnya menjadi pembelajaran yang menyenangkan dan interaktif bagi siswa, yang memberikan kesempatan pada guru dan siswa untuk terlibat secara aktif dalam menggunakan dan mengembangkan keterampilan-keterampilan berbahasa khususnya pengembangan kompetensi keterampilan berbicara. 
Berbicara adalah aktivitas berbahasa yang dilakukan manusia atau dapat dikatakan proses individu berkomunikasi dengan cara menuangkan buah pikiran, gagasan, dan perasaan ke dalam bahasa lisan melalui kalimat yang dirangkai secara utuh, lengkap, jelas, dan komunikatif. "Berbicara merupakan proses individu berkomunikasi, maka dalam pelaksanaan pembelajaran, siswa diharapkan dapat belajar dalam proses komunikasi" (Juliati, 2013:2). Hal serupa disampaikan Fadhila (2016) bahwa berbicara merupakan aktivitas berbahasa yang dilakukan manusia yang bersifat produktif artinya kegiatan yang menyampaikan pesan, pemikiran, gagasan, dan perasaan melalui bahasa. Jadi, dapat diartikan kompetensi keterampilan berbicara merupakan kemampuan dari aspek pengetahuan, sikap, dan keterampilan dalam mereproduksi sistem bunyi artikulasi untuk mengekspresikan pikiran dan perasaan secara lisan dan secara cerdas sesuai konteks dan situasi.

Berdasarkan hasil observasi dan wawancara yang dilaksanakan di SD Gugus Budi Utomo, bahwa keterampilan berbicara siswa berada pada taraf yang perlu untuk dioptimalkan. Hal tersebut dapat dilihat selama proses pembelajaran, siswa masih merasa malu dan gugup ketika diminta untuk menyampaikan pendapatnya. Selain itu, dalam pelaksanaan pembelajaran di sekolah siswa belum menerapkan model pembelajaran role playing.

Keberhasilan proses pembelajaran tidak terlepas dari kemampuan guru mengembangkan model-model pembelajaran yang berorientasi pada peningkatan intensitas keterlibatan siswa secara efektif di dalam proses pembelajaran. Seluruh aktivitas pembelajaran yang dirancang dan dilaksanakan oleh guru harus bermuara pada terjadinya proses belajar siswa. Sangat penting melaksanakan variasi dalam pembelajaran dengan menerapkan model pembelajaran yang inovatif sehingga siswa dapat memperoleh hasil belajar yang optimal. Model pembelajaran role playing adalah model pembelajaran bermain peran, selama pelaksanaannya siswa akan memerankan berbagai tokoh yang terdapat dalam cerita dengan pengembangan imajinasi dan penghayatan siswa sehingga siswa dapat mengimplementasikan hubungan-hubungan antar manusia dengan cara memperagakan, mendiskusikan, dan mengkomunikasikan. "Model pembelajaran role playing merupakan cara penguasaan bahanbahan pelajaran melalui pengembangan imajinasi dan penghayatan siswa terhadap materi" (Kurniasih dan Sani, 2017:68). Hal serupa disampaikan Komalasari (2011:80) bahwa "role playing adalah suatu model penguasaan bahan-bahan pelajaran melalui pengembangan imajinasi dan pengahayatan siswa".

Melalui model pembelajaran role playing dapat membangkitkan gairah dan mengurangi kegugupan siswa dalam berbicara, karena dilaksanakan bersama-sama dengan teman satu kelompok. Role playing sering kali dimaksudkan sebagai suatu bentuk aktivitas dimana pembelajar membayangkan dirinya seolah-olah berada di luar kelas dan memainkan peran orang lain (Huda, 2016). Pengembangan imajinasi dan pengahayatan dilakukan siswa dengan memerankannya sebagai tokoh hidup atau mati. Selain itu, model pembelajaran role playing juga dapat digunakan untuk meningkatkan rasa percaya diri siswa dalam berbicara dihadapan banyak orang. Pada pembelajaran role playing, siswa dapat bertindak dan mengekpresikan perasaan dan pendapat tanpa kekhawatiran mendapat sanksi, memberikan kepada siswa kesenangan karena role playing pada dasarnya adalah permainan.

Model pembelajaran role playing dapat melibatkan aspek-aspek kognitif, afektif maupun psikomotor para siswa. Aspek kognitif meliputi pemecahan masalah, aspek afektif meliputi sikap, nilai-nilai pribadi/orang lain, membandingkan, mempertentangkan nilai-nilai, dan mengembangkan empati atas dasar tokoh yang mereka perankan, sedangkan aspek psikomotor terlihat ketika siswa memainkan

peran di depan kelas.

Model pembelajaran role playing sebagai salah satu model pembelajaran inovatif yang dapat digunakan pada muatan materi bahasa Indonesia khususnya keterampilan berbicara. Terutama model pembelajaran role playing berbantuan teks dialog menciptakan siswa lebih aktif, pembelajaran menjadi menyenangkan, dan lebih bermakna. Siswa juga dapat bereksplorasi memperagakan tokoh yang ada dalam teks dialog, memperagakan tingkah laku manusia secara mendasar yang dihayati oleh pemainnya dan diterima oleh penonton yang merasakannya sebagai suatu kenyataan. 
Teks adalah ujaran (lisan) atau tulis bermakna yang berfungsi untuk mengekspresikan gagasan (Priyatni, 2014). Teks adalah pesan-pesan tertulis atau produk bahasa dalam bentuk tulisan (Piliang, 2017). Hal serupa disampaikan Putri dan Rahmadona (2016) bahwa teks adalah ungkapan pikiran manusia yang lengkap yang di dalamnya ada situasi dan konteksnya. Berdasarkan pemaparan pendapat tersebut, maka dapat disimpulkan bahwa teks adalah produk bahasa melalui mengekspresikan gagasan dalam bentuk tulisan berisi situasi dan konteksnya. Dialog adalah percakapan yang dilakukan oleh dua orang atau lebih dan peserta dialog mempunyai hak yang sama untuk menyumbangkan gagasannya mengenai suatu topik pembicaraan. Pernyataan ini sesuai dengan pendapat Lestari dan Sukartiningsih (2015:2078) bahwa dialog merupakan percakapan, pertukaran pikiran atau pendapat yang dilakukan antara dua orang atau lebih mengenai suatu topik pembicaraan.

Berdasarkan pemaparan tersebut, maka dapat disimpulkan bahwa teks dialog adalah karya tulis yang disajikan dalam bentuk percakapan, menampilkan dua orang atau lebih sebagai komunikasi yang mendalam yang mempunyai tingkat dan kualitas tinggi dan saling berbagi pandangan satu sama lain. Hal serupa disampaikan Rusmana (2013:2) bahwa "teks dialog adalah karya tulis yang disajikan dalam bentuk percakapan antara dua tokoh atau lebih". Kemampuan yang dapat dikembangkan dari bermain peran berbantuan teks dialog seperti kemampuan berkomunikasi, kemampuan menghafal, dan kemampuan mengaktualisasikan diri ke dalam situasi yang dihadapi, sehingga model pembelajaran role playing berbantuan teks dialog merupakan suatu model pembelajaran yang mengembangkan kreatifitas siswa dalam berimajinasi dengan teks dialog untuk dapat mengingat, menghayati, dan memahami materi yang diajarkan serta dapat mempengaruhi kompetensi keterampilan berbicara dalam bahasa Indonesia. Karena model pembelajaran role playing berbantuan teks dialog dapat membangkitkan keinginan dan minat baru, membangkitkan motivasi, dan rangsangan kegiatan belajar. Hal tersebut akan mampu menyiapkan siswa terampil dalam berbicara sebagai sarana komunikasi dalam kehidupan sehari-hari di masa yang akan datang.

Adapun keunggulan model pembelajaran role playing berbantuan teks dialog, yaitu (1) dapat melatih rasa percaya diri siswa terutama ketika berhadapan dengan banyak orang; (2) melatih daya ingat siswa serta dapat memahami, mengahayati, dan meningkatkan minat siswa dalam proses pembelajaran; (3) melatih kompetensi keterampilan berbicara siswa dan dapat mengekspresikan isi teks dialog tersebut; dan (4) melibatkan siswa aktif secara menyeluruh baik dari sisi afektif (sikap), kognitif (pengetahuan), dan

psikomotorik (keterampilan).

Berdasarkan pemaparan tersebut, tujuan penelitian ini adalah untuk mengetahui perbedaan yang signifikan kompetensi keterampilan berbicara dalam bahasa Indonesia antara kelompok siswa yang dibelajarkan dengan menggunakan model pembelajaran role playing berbantuan teks dialog dengan kelompok siswa yang dibelajarkan dengan menggunakan pembelajaran konvensional pada siswa kelas IV SD Gugus Budi Utomo

tahun ajaran 2017/2018.

\section{Metode Penelitian}

Jenis penelitian yang digunakan dalam penelitian ini adalah penelitian kuantitatif dengan menggunakan rancangan quasi experimental design, yaitu "non-equivalent post-test only control group design" (Agung, 2014:163). Rancangan penelitian disajikan pada Tabel 1.

Tabel 1. Rancangan Penelitian Non-Equivalent Post-Test Only Control Group Design

\begin{tabular}{lcc}
\hline Kelas & Perlakuan & Post-Test \\
Eksperimen & $\mathrm{X}_{1}$ & $\mathrm{O}_{1}$ \\
Kontrol & - & $\mathrm{O}_{2}$ \\
\hline
\end{tabular}

Desain yang digunakan melibatkan dua kelompok kelas yaitu kelompok kelas eksperimen dan kelompok kelas kontrol. Satu kelompok kelas sebagai kelompok 
eksperimen diberikan perlakuan, yaitu dengan menerapkan model pembelajaran role playing berbantuan teks dialog sedangkan satu kelompok kelas sebagai kelompok kontrol diberikan pembelajaran konvensional. Tetapi kelompok kontrol tidak dapat berfungsi sepenuhnya untuk mengontrol variabel-variabel luar yang mempengaruhi pelaksanaan eksperimen.

Populasi penelitian ini adalah seluruh siswa kelas IV SD Gugus Budi Utomo tahun ajaran 2017/2018, yang terdiri dari 9 kelas dalam 7 SD. Jumlah populasi penelitian ini adalah 315 siswa. Teknik pengambilan sampel ditentukan dengan menggunakan teknik sampel kelompok, yaitu sampel yang diambil dari kelompok-kelompok yang telah ditentukan seperti menggunakan kelas atau kelompok (Setyosari, 2016). Pada pemilihan sampel penelitian ini dilakukan tanpa pengacakan individu melainkan pengacakan kelas karena kelas telah terbentuk sebelumnya tanpa campur tangan peneliti. Hal ini bertujuan untuk menghindari kemungkinan dari siswa yang mengetahui dirinya terlibat dalam eksperimen sehingga penelitian ini benar-benar menggambarkan pengaruh perlakuan yang diberikan. Penentuan sampel dilakukan dengan cara memberikan nomor pada masing-masing kelas IV di SD Gugus Budi Utomo kemudian dilakukan pengundian. Pengundian dilakukan agar semua anggota populasi memiliki kesempatan yang sama untuk dipilih menjadi sampel penelitian. Berdasarkan hasil pengundian, didapatkan dua kelas sebagai sampel penelitian, yaitu kelas IVB di SD Negeri 6 Kesiman sebagai kelompok eksperimen dan kelas IV di SD Negeri 14 Kesiman sebagai kelompok kontrol.

Metode pengumpulan data yang digunakan pada penelitian ini adalah metode non tes, yaitu metode observasi partisipasi. Observasi peran serta (participant observation) diartikan sebagai pelaksanaan pengamatan, peneliti ikut melakukan apa yang dikerjakan oleh sumber data, dan ikut merasakan suka dukanya maka data yang diperoleh akan lebih lengkap, tajam, dan sampai mengetahui pada tingkat makna dari setiap perilaku yang nampak (Sugiyono, 2017). Berdasarkan hal tersebut, metode observasi partisipasi berkaitan dengan penilaian tingkah laku atau sebuah keterampilan. Untuk mengumpulkan data dan mengukur kompetensi keterampilan berbicara dalam bahasa Indonesia siswa, digunakan rubrik penilaian. Indikator rubrik penilaian disederhanakan ke dalam dua faktor, yaitu pertama faktor kebahasaan yang terdiri atas pelafalan, intonasi, pemahaman, struktur kalimat, dan kelancaran. Kedua, faktor non kebahasaan yang terdiri atas ekspresi, gestur/gerak-gerik, dan etika. Sebelum melakukan penelitian, dilakukan uji ahli terhadap rubrik penilaian.

Analisis data yang digunakan adalah analisis statistik inferensial. Analisis statistik inferensial digunakan untuk menguji kebenaran hipotesis penelitian. Dalam penelitian ini uji hipotesis akan dianalisis dengan menggunakan uji t dengan rumus polled varians. Sebelum dilakukan uji $\mathrm{t}$, terlebih dahulu dilaksanakan uji prasyarat yang meliputi uji normalitas sebaran data dengan rumus chi-square dan uji homogenitas varians dilakukan dengan uji F.

\section{Hasil dan Pembahasan}

Data hasil kompetensi keterampilan berbicara dalam bahasa Indonesia diperoleh dari hasil post-test. Untuk mengetahui perbedaan yang signifikan kompetensi keterampilan berbicara dalam bahasa Indonesia antara kelompok siswa yang dibelajarkan dengan menggunakan model pembelajaran role playing berbantuan teks dialog dengan kelompok siswa yang dibelajarkan dengan menggunakan pembelajaran konvensional, perlu dilakukan uji hipotesis. Sebelum dilakukan uji hipotesis, terlebih dahulu dilaksanakan uji prasyarat yang meliputi uji normalitas sebaran data dan uji homogenitas varians terhadap data keterampilan berbicara dalam bahasa Indonesia siswa.

Uji normalitas sebaran data dalam penelitian ini menggunakan rumus chi-square, kriteria pengujian adalah jika harga $X_{\text {hitung }}^{2}>X_{\text {tabel }}^{2}$ maka $\mathrm{H}_{\mathrm{o}}$ ditolak dan $\mathrm{H}_{\mathrm{a}}$ diterima (gagal ditolak), ini berarti data tidak berdistribusi normal. Berdasarkan hasil uji normalitas sebaran data kelompok eksperimen diperoleh chi-square hitung $\left(X_{\text {hitung }}^{2}=2,38\right)$, harga tersebut kemudian dibandingkan dengan harga $X_{\text {tabel }}^{2}$ pada taraf signifikan $5 \%$ dengan $\mathrm{dk}=5$ 
sehingga diperoleh harga $X_{\text {tabel }}^{2}=11,07$, dengan demikian $X_{\text {hitung }}^{2}=2,38<X_{\text {tabel }}^{2}(\alpha=0,05)$ 11,07 , maka $H_{o}$ diterima atau $H_{a}$ ditolak yang berarti sebaran data kompetensi keterampilan berbicara dalam bahasa Indonesia kelompok eksperimen berdistribusi normal.

Berdasarkan hasil uji normalitas sebaran data kelompok kontrol diperoleh chi-square hitung $\left(X_{\text {hitung }}^{2}=5,64\right)$, harga tersebut kemudian dibandingkan dengan harga $X_{\text {tabel }}^{2}$ pada taraf signifikan $5 \%$ dengan $\mathrm{dk}=5$ sehingga diperoleh harga $X_{\text {tabel }}^{2}=11,07$, dengan demikian $X_{\text {hitung }}^{2}=5,64<X_{\text {tabel }(\alpha=0,05)}^{2}=11,07$, maka $\mathrm{H}_{0}$ diterima atau $\mathrm{H}_{\mathrm{a}}$ ditolak. Hal ini berarti sebaran data kompetensi keterampilan berbicara dalam bahasa Indonesia kelompok kontrol berdistribusi normal.

Setelah diketahui hasil uji normalitas sebaran data berdistribusi normal, selanjutnya dilakukan uji homogenitas varians dengan rumus uji F. Diketahui $F_{\text {hitung }}=1,58$ dan $F_{\text {tabel }}=$ 1,78, dengan demikian $F_{\text {hitung }}=1,58<F_{\text {tabel }(\alpha=0,05)}=1,78$, maka $\mathrm{H}_{0}$ diterima atau $\mathrm{H}_{\mathrm{a}}$ ditolak. Hal ini berarti bahwa varians antara kelompok eksperimen dan kelompok kontrol homogen.

Berdasarkan uji prasyarat analisis data, diperoleh bahwa data keterampilan berbicara siswa kelompok eksperimen dan kelompok kontrol adalah berdistribusi normal dan homogen, dengan demikian uji hipotesis menggunakan uji t dengan rumus polled varians dapat dilakukan.

Hipotesis yang diuji dalam penelitian ini adalah hipotesis nol $\left(\mathrm{H}_{0}\right)$ yang menyatakan bahwa tidak terdapat perbedaan yang signifikan kompetensi keterampilan berbicara dalam bahasa Indonesia antara kelompok siswa yang dibelajarkan dengan model pembelajaran role playing berbantuan teks dialog dengan kelompok siswa yang dibelajarkan menggunakan model pembelajaran konvensional pada siswa kelas IV SD Gugus Budi Utomo tahun ajaran 2017/2018. Adapun hasil analisis uji t disajikan pada Tabel 2.

Tabel 2. Hasil Analisis Uji T

\begin{tabular}{cccccccc}
\hline No. & Sampel & Rata-rata & Varians & $\mathrm{N}$ & $t_{\text {hitung }}$ & $t_{\text {tabel }}$ & Kesimpulan \\
\hline 1 & Kelompok Eksperimen & 85,00 & 107,92 & 31 & & & \\
2 & Kelompok Kontrol & 76,45 & 68,12 & 38 & 3,81 & 2,00 & $\mathrm{H}_{\mathrm{a}}$ Diterima \\
\hline
\end{tabular}

Berdasarkan hasil analisis data diperoleh $t_{\text {hitung }}=3,81$ dan $t_{\text {tabel }}$ pada taraf signifikansi $5 \%$ dengan derajat kebebasan $\left(\mathrm{dk}=31+38-2=67\right.$ ), diperoleh $t_{\text {tabel }}$ adalah 2,00 . Karena $t_{\text {hitung }}=3,81>t_{\text {tabel }(\alpha=0,05)}=2,00$, dengan demikian hipotesis nol $\left(\mathrm{H}_{0}\right)$ ditolak. Hal ini berarti terdapat perbedaan yang signifikan kompetensi keterampilan berbicara dalam bahasa Indonesia antara kelompok siswa yang dibelajarkan dengan model pembelajaran role playing berbantuan teks dialog dengan kelompok siswa yang dibelajarkan menggunakan pembelajaran konvensional pada siswa kelas IV SD Gugus Budi Utomo tahun ajaran 2017/2018.

Berdasarkan hasil temuan tersebut, dapat dinyatakan kedua kelompok sampel penelitian yang memiliki kemampuan setara, setelah diberikan perlakuan berupa pembelajaran dengan menggunakan model pembelajaran role playing berbantuan teks dialog dan mengikuti pembelajaran menggunakan pembelajaran konvensional diperoleh hasil penguasaan kompetensi keterampilan yang berbeda.

Adanya perbedaan yang signifikan menunjukan bahwa model pembelajaran role playing berbantuan teks dialog berpengaruh terhadap kompetensi keterampilan berbicara dalam bahasa Indonesia siswa. Penyebab dari adanya perbedaan tersebut adalah karena adanya perbedaan perlakuan pada langkah-langkah pembelajaran seperti halnya pemberian materi pada awal hingga akhir pembelajaran.Pada kelompok eksperimen diberikan perlakuan model pembelajaran role playing berbantuan teks dialog. Model pembelajaran role playing berbantuan teks dialog merupakan suatu inovasi pembelajaran yang mendorong siswa untuk berbicara karena dalam proses pembelajaran siswa memainkan sebuah peran yang terjadi 
saat ini atau yang telah terjadi pada masa lampau. Adanya kegiatan bermain peran berbantuan teks dialog tersebut menjadikan siswa dapat mengembangkan role playing berbantuan teks dialog. Adanya kegiatan bermain peran berbantuan teks dialog tersebut menjadikan siswa dapat mengembangkan imajinasi, penghayatan, dan dapat melatih rasa percaya diri siswa terutama ketika berhadapan dengan banyak orang. Pembelajaran menggunakan model pembelajaran role playing berbantuan teks dialog pada muatan materi bahasa Indonesia memberikan kesempatan yang lebih luas kepada siswa untuk mengkonstruksi keterampilannya melalui berbagai kegiatan bermakna dan teratur yang tentunya menggembirakan bagi siswa pada setiap langkah pembelajarannya. Pembelajaran tersebut berbeda dengan perlakuan yang diberikan pada kelompok kontrol yang pembelajarannya lumrah atau sering digunakan oleh guru dalam proses pembelajaran di kelas, yaitu menggunakan pendekatan saintifik dengan tidak adanya penggunaan media pembelajaran.

Pembelajaran pada kelompok eksperimen dan kelompok kontrol sama-sama menggunakan pendekatan saintifik dengan menerapkan kurikulum 2013 dan sama-sama menggunakan tema daerah tempat tinggalku dalam proses pembelajarannya. Tetapi yang membedakan di kelas eksperimen menggunakan model role playing berbantuan teks dialog yang menjadikan pembelajaran lebih menarik dan menyenangkan sehingga mampu membangkitkan semangat dan minat siswa untuk belajar sehingga pada akhirnya akan berpengaruh terhadap kompetensi keterampilan yang dimiliki siswa. Serta selama kegiatan pembelajaran siswa lebih aktif karena kegiatan pembelajaran menggunakan model pembelajaran role playing berbantuan teks dialog menciptakan lingkungan belajar yang memberikan kegembiraan melalui pemeranan suatu tokoh, menirukan kehidupan, sifat, dan sikap tokoh-tokoh selama pemeranan berlangsung. Sedangkan pada kelompok kontrol dengan menggunakan pembelajaran konvensional yang kegiatan pembelajarannya menoton membuat siswa merasa kurang bersemangat sehingga keadaan siswa pasif dalam belajar.

Pengaruh antara model pembelajaran role playing berbantuan teks dialog dengan pembelajaran konvensional dapat dilihat dari perolehan hasil perhitungan analisis data yang dilakukan menunjukkan bahwa nilai rata-rata (mean) siswa yang dibelajarkan menggunakan model pembelajaran role playing berbantuan teks dialog $(\bar{X}=85,00)$ dan siswa yang dibelajarkan menggunakan pembelajaran konvensional $(\bar{X}=76,45)$ memiliki perbedaan sebesar 8,55. Dengan demikian, terdapat pengaruh kompetensi keterampilan berbicara dalam bahasa Indonesia antara siswa kelas IV di SD Gugus Budi Utomo tahun ajaran 2017/2018 yang dibelajarkan menggunakan model pembelajaran role playing berbantuan teks dialog dan siswa yang dibelajarkan menggunakan pembelajaran konvensional pada tema daerah tempat tinggalku.

Hasil penelitian ini memperkuat simpulan yang disampaikan oleh Wimpiadi (2014) dengan judul "Pengaruh Penerapan Model Pembelajaran Role playing terhadap Keterampilan Berbicara Bahasa Indonesia Siswa Kelas IV SDN 10 Pemecutan". Berdasarkan pemaparan tersebut, dapat disimpulkan bahwa terdapat pengaruh model pembelajaran role playing berbantuan teks dialog terhadap kompetensi keterampilan berbicara dalam bahasa Indonesia siswa kelas IV SD Gugus Budi Utomo tahun ajaran 2017/2018.

\section{Simpulan dan Saran}

Berdasarkan hasil analisis uji t diperoleh $t_{\text {hitung }}=3,81$. Harga tersebut kemudian dibandingkan dengan harga $t_{\text {tabel }}$ pada taraf signifikansi $5 \%$ dengan $(\mathrm{dk}=31+38-2=67$ ) adalah 2,00. Oleh karena $t_{\text {hitung }}=3,81>t_{\text {tabel }(\alpha=0,05)}=2,00$, maka $\mathrm{H}_{\mathrm{a}}$ diterima atau $\mathrm{H}_{0}$ ditolak. Hal ini berarti terdapat perbedaan yang signifikan kompetensi keterampilan berbicara dalam bahasa Indonesia antara kelompok siswa yang dibelajarkan menggunakan model pembelajaran role playing berbantuan teks dialog dengan kelompok siswa yang dibelajarkan menggunakan pembelajaran konvensional pada siswa kelas IV SD Gugus Budi Utomo tahun ajaran 2017/2018. Rata-rata kompetensi keterampilan berbicara dalam bahasa Indonesia pada 
siswa kelas IVB SD Negeri 6 Kesiman yang dibelajarkan menggunakan model pembelajaran role playing berbantuan teks dialog sebesar $(\bar{X}=85,00)$ dan rata-rata kompetensi keterampilan berbicara dalam bahasa Indonesia pada siswa kelas IV SD Negeri 14 Kesiman yang dibelajarkan menggunakan pembelajaran konvensional sebesar $(\bar{X}=76,45)$. Dengan demikian terdapat pengaruh model pembelajaran role playing berbantuan teks dialog terhadap kompetensi keterampilan berbicara dalam bahasa Indonesia siswa kelas IV SD Gugus Budi Utomo tahun ajaran 2017/2018.

Berdasarkan hasil penelitian ini maka saran yang dapat disampaikan yaitu: kepada guru disarankan agar lebih kreatif untuk memberikan fasilitas berupa sumber belajar, dan kesempatan yang lebih besar bagi siswa pada pembelajaran, dengan menggunakan model pembelajaran role playing berbantuan teks dialog, sehingga tercipta pembelajaran bermakna bagi siswa. Selanjutnya kepada kepala sekolah, disarankan agar dapat menggunakan hasil penelitian ini, sebagai pendukung sumber belajar guru dalam meningkatkan kualitas pembelajaran, sehingga sekolah mampu menghasilkan siswa yang berkualitas. Selanjutnya kepada peneliti lain agar melakukan penelitian lebih lanjut dengan menggunakan model pembelajaran role playing berbantuan teks dialog. Dapat pula dilakukan penelititan lebih lanjut dengan menggunakan model pembelajaran role playing berbantuan teks dialog pada sumber data/sampel yang berbeda khususnya pada muatan materi bahasa Indonesia sehingga hasil penelitian benar-benar dapat menggambarkan keadaan sesungguhnya yang terjadi di lapangan.

\section{Daftar Pustaka}

Agung, A. A. Gede. 2014. Buku Ajar Metodologi Penelitian Pendidikan. Malang: Aditya Media Publishing.

Fadhila, Afina Nur, dkk. 2016. "Peningkatan Kompetensi keterampilan berbicara dengan Menggunakan Model Pembelajaran Kooperatif Tipe Time Token". Jurusan Pendidikan Guru Sekolah Dasar FKIP UNS, (hlm.1-5) (diakses tanggal 10 Januari 2018).

Huda, Miftahul. 2016. Model-model Pengajaran dan Pembelajaran. Yogyakarta: Pustaka Pelajar.

Juliati, Ni Wayan, dkk. 2013. "Pengaruh Pembelajaran Time Token Berbantuan Gambar Berseri terhadap Kompetensi keterampilan berbicara Siswa Kelas V SD Gugus I Gianyar". Jurusan Pendidikan Guru Sekolah Dasar FIP Undiksha, Volume 2, Nomor 1 (hlm.1-10) (diakses tanggal 10 Januari 2018).Kurniasih, Imas dan Berlin Sani. 2017. Ragam Pengembangan Model Pembelajaran untuk Peningkatan Profesionalitas Guru. Jakarta: Kata Pena.

Komalasari, Kokom. 2011. Pembelajaran Kontekstual Konsep dan Aplikasi. Bandung: PT Refika Aditama.

Kurniasih, Imas dan Berlin Sani. 2017. Ragam Pengembangan Model Pembelajaran untuk Peningkatan Profesionalitas Guru. Jakarta: Kata Pena.Lestari, Novi Elyana dan Wahyu Sukartiningsih. 2015. "Pengaruh Penggunaan Media Komik Tanpa Dialog terhadap Kemampuan Menulis Teks Dialog Siswa Kelas III SD Kecamatan Wiyung Surabaya". Jurusan Pendidikan Guru Sekolah Dasar FIP UNESA, Volume 3, Nomor 2 (hlm.20772086) (diakses tanggal 24 Januari 2018).

Piliang, Yasraf Amir. 2004. "Semiotika Teks: Sebuah Pendekatan Analisis Teks". Mediator, Volume 5, Nomor 2 (hlm.189-198) (diakses tanggal 23 Januari 2018). 
Priyatni, Endah Tri. 2014. Desain Pembelajaran Bahasa Indoesia dalam Kurikulum 2013. Jakarta: Bumi Aksara.

Putri, Mega dan Melia Rahmadona. 2016. "Kemampuan Menulis Teks Biografi Siswa Kelas VIII SMP Negeri 2 Kota Solok". Bahastra Universitas Mahaputra Muhammad Yamin Solok Sumbar, Volume XXXVI, Nomor 1 (hlm.85-97) (diakses tanggal 23 Januari 2018).

Rusmana, Mulia Ardi. 2013. "Pembelajaran Menulis Teks Dialog dengan Menggunakan Metode Environment learning Pada Siswa Kelas V SDN I Leuwianyar Bandung". Program Studi Bahasa dan Sastra Indonesia Sekolah Tinggi Keguruan dan IImu Pendidikan Siliwangi Bandung (hlm.1-6) (diakses tanggal 18 Januari 2018).Setyosari, Punaji. 2016. Metode Penelitian Pendidikan dan Pengembangan. Jakarta: Prenadamedia Group.

Setyosari, Punaji. 2016. Metode Penelitian Pendidikan dan Pengembangan. Jakarta: Prenadamedia Group.Sugiyono. 2017. Metode Penelitian Kuantitatif, Kualitatif, dan R\&D. Bandung: Alfabeta.

Standar Isi untuk Satuan Pendidikan Dasar dan Menengah, 2006. Jakarta: BNSP.

Sugiyono. 2017. Metode Penelitian Kuantitatif, Kualitatif, dan R\&D. Bandung: Alfabeta.

Susanto, Ahmad. 2014. Teori Belajar dan Pembelajaran di Sekolah Dasar. Jakarta: PT Interpratama Mandiri.

Wimpiadi, I Kadek, dkk. 2014. "Pengaruh Penerapan Model Pembelajaran Role Playing terhadap Keterampilan Berbicara Bahasa Indonesia Siswa Kelas IV SDN 10 Pemecutan". Jurusan Pendidikan Guru Sekolah Dasar FIP Undiksha, Volume 2, Nomor 1 (hlm.1-11) (diakses tanggal 13 April 2018). 